\title{
Influence of Starkeya novella on Mechanical and Microstructural Properties of Cement Mortars
}

\author{
Onesmus Mulwa Munyao $\mathbb{D}^{1},{ }^{1}$ Joseph Karanja Thiong'o, ${ }^{1}$ Jackson Muthengia Wachira $\left(\mathbb{D},{ }^{2}\right.$ \\ Daniel Karanja Mutitu $\mathbb{D}^{2},{ }^{2}$ and Romano Mwirichia ${ }^{3}$ \\ ${ }^{1}$ Department of Chemistry, Kenyatta University, Nairobi, Kenya \\ ${ }^{2}$ Department of Physical Sciences, University of Embu, Embu, Kenya \\ ${ }^{3}$ Department of Biological Sciences, University of Embu, Embu, Kenya \\ Correspondence should be addressed to Onesmus Mulwa Munyao; onesmusmulwa@gmail.com
}

Received 18 February 2020; Revised 24 April 2020; Accepted 5 May 2020; Published 18 May 2020

Academic Editor: Christophe Petit

Copyright (C) 2020 Onesmus Mulwa Munyao et al. This is an open access article distributed under the Creative Commons Attribution License, which permits unrestricted use, distribution, and reproduction in any medium, provided the original work is properly cited.

\begin{abstract}
Cement-based materials are subject to degradation during their service life. Most of the structural failures have been associated with corrosion of the rebar due to chloride ingress, alkali aggregate reaction, and/or sulfate attack. Microbial activities, especially in waste water collection points such as sewer lines, may compromise the integrity of concrete structures. This study reports an experimental work carried out to determine the effect of Starkeya novella bacteria species on mechanical and microstructural properties of cement mortars. Mortar prisms were prepared from selected ordinary Portland cement (OPC) and Portland pozzolana cement (PPC) in Kenyan markets. Bacterial solution of $1.0 \times 10^{7}$ cell $/ \mathrm{mL}$ concentration was used as either mix water, curing media, or both. Distilled water was used to prepare mortar prisms for control samples. Compressive strength was determined after the $7^{\text {th }}, 28^{\text {th }}, 56^{\text {th }}$, and $90^{\text {th }}$ day of curing. Scanning electron microscopy (SEM) was tested on both bacterial and control mortar prisms after the $28^{\text {th }}$ day of curing. Both PPC and OPC exhibited significant decrease in compressive strength for bacterial-prepared mortars as compared to controls. SEM analysis showed extreme erosion on the microstructure of the microbial mortars. This was denoted by massive formation of ettringite and gypsum which are injurious to mortar/concrete.
\end{abstract}

\section{Introduction}

Concrete and/or mortar is used globally in large volumes for construction of roads, bridges, sewage systems, and/or railway lines [1]. Concrete and/or mortar durability is a key aspect in evaluating the service life of cement-based structures. Cement-based materials are subject to degradation due to influence of external processes such as carbonation, sulphate attack, and/or chloride ingress [1-3]. Exposure of concrete structures into aggressive environment initiates degradation mechanisms that result in failure and/or increased repair expenses of critical civil structures.

Most of transport and collection systems such as sewer lines are made of cement mortar/concrete. These structures are susceptible to degradation due to microbial activities that enable a chemically aggressive environment suitable for degeneration of such structures [4]. Even though microorganisms form invisible thin biofilms on the surfaces of concrete, they are capable of degrading concrete-made structures $[5,6]$. While a number of studies have been conducted to investigate the effect of chemical sulphuric acid on the degradation of concrete, little attention has been given to degrading microorganisms present in aggressive environments such as sewer systems $[7,8]$.

Microbial metabolism results in synthesis of hydrogen sulphide $\left(\mathrm{H}_{2} \mathrm{~S}\right)$ by sulphur reducing bacteria (SRB) in the sewer lines. The formed hydrogen sulphide is biologically oxidized to form biogenic sulphuric acid $\left(\mathrm{H}_{2} \mathrm{SO}_{4}\right)$ [9]. The formed biogenic sulphuric acid lowers the concrete $\mathrm{pH}$ which is a suitable condition for biodegradation [10]. Additionally, the formed acid may react with cement mortar/ concrete constituents to form other deleterious expansive 
products such as gypsum and ettringite $[10,11]$. This form of concrete degradation is commonly referred to as microbially induced deterioration (MID) [4].

Structural failures due to MID reduces the service life of concrete-based structures from the projected 100 years to virtually 30-50 years. In severe environs, the service life of the concrete may be reduced to 10 years [12]. This form of concrete structural failures not only contributes to increased cost of repair, but it has a huge negative effect on health and environment. This is due to production of unpleasant gases such as hydrogen sulphide [4, 13-15]. Biodeterioration of cement-based materials involves a series of chemical, physical, and biological reactions that take place in an intricate system involving microbes, material, and the surrounding environment [16].

Concrete deterioration as a result of microbial attack was first documented by Parker [6]. He (Parker) isolated 5 strains of Thiobacillus species bacteria from corroded concrete surface and reported that the isolated bacteria strains had the ability to produce biogenic acid leading to concrete corrosion. Munyao et al., 2020 [17], reported that Thiobacillus intermedius degrades the microstructure of ordinary Portland cement mortar. Several other researchers have shown that the activity of Thiobacillus species in degrading concrete structures increases with increase in moisture, oxygen, and hydrogen sulphide $[18,19]$.

In developing countries such as Kenya, there are many reported cases of structural failures that culminated to deaths and/or lose of properties. Majority of these failures are attributed to poor workmanship, inconsistency in quality of other materials such as sand, aggregates, and mixing water. While a lot of research in this region has been conducted to investigate the use of other cementitious materials such as pozzolans in improving the properties of existing ordinary Portland cement (OPC) and the desired quality of mixing water, very little attention has been given to the contribution of microbes on the performance of cement-based materials.

Starkeya novella formerly referred to as Thiobacillus novellus was first isolated by Starkey $[20,21]$. Some researchers were able to show that Thiobacillus novellus currently referred to as Starkeya novella has the ability to grow chemolithoautotrophically with thiosulphate as a source of energy [22]. The work conducted in this experiment involved simulated laboratory studies to determine the influence of Starkeya novella bacteria species on mechanical and microstructural properties of cement mortars of PPC and OPC.

\section{Materials and Methods}

2.1. Materials. Test cements of the type ordinary Portland cement (OPC) CEM I 42.5 and Portland pozzolana cement (PPC) CEM IV 32.5 conforming to KS EAS 18:1- 2017 [23] were sampled from a local cement manufacturing plant in Kenya. ISO standard sand purchased from the Societe Nouvelle Du Littoral company was used in preparation of test mortar prisms as described in EN 196-1 [24]. The composition of the test cements used in this experiment was as presented in Table 1. Analytical grade (AR) reagents were used to prepare
TABle 1: Chemical composition of test cements.

\begin{tabular}{lcc}
\hline \% Oxide Composition & OPC & PPC \\
\hline $\mathrm{CaO}$ & 64.8 & 45.6 \\
$\mathrm{MgO}$ & 1.1 & 0.9 \\
$\mathrm{Al}_{2} \mathrm{O}_{3}$ & 5.4 & 10.7 \\
$\mathrm{Fe}_{2} \mathrm{O}_{3}$ & 3.4 & 5.3 \\
$\mathrm{SiO}_{2}$ & 20.7 & 32.6 \\
$\mathrm{SO}_{3}$ & 2.3 & 2.1 \\
$\mathrm{~K}_{2} \mathrm{O}$ & 0.3 & 0.35 \\
$\mathrm{Na}_{2} \mathrm{O}$ & 0.2 & 0.25 \\
$\mathrm{LOI}$ & 1.8 & 2.2 \\
\hline
\end{tabular}

the media culture for the bacteria. The chemical reagents included calcium chloride $\left(\mathrm{CaCl}_{2}\right)$, agar, dipotassium phosphate $\left(\mathrm{K}_{2} \mathrm{HPO}_{4}\right)$, sodium thiosulphate pentahydrate $\left(\mathrm{Na}_{2} \mathrm{SO}_{3} .5 \mathrm{H}_{2} \mathrm{O}\right)$, iron (III) chloride hexahydrate $\left(\mathrm{FeCl}_{3} \cdot 6 \mathrm{H}_{2} \mathrm{O}\right)$, manganese (II) sulphate monohydrate $\left(\mathrm{MnSO}_{4} \cdot \mathrm{H}_{2} \mathrm{O}\right)$, magnesium sulphate heptahydrate $\left(\mathrm{MgSO}_{4} \cdot 7 \mathrm{H}_{2} \mathrm{O}\right)$, and ammonium sulphate, $\left(\left(\mathrm{NH}_{4}\right)_{2} \mathrm{SO}_{4}\right)$. Starkeya novella bacteria designated as DSM 506 was acquired from Leibniz-Institut DSMZ Deutsche Sammlung Von Mikroorganismen und Zellkulture GmbH, Germany. The culturing medium was prepared using sterilized distilled water.

\subsection{Methods}

2.2.1. Determination of Cement Oxides. The chemical composition of each test cement was determined using X-ray fluorescence technique (XRF). The PANalytical XRF equipment model Epsilon $3^{\mathrm{XLE}}$ was used in this experiment. $0.900 \mathrm{~g}$ of each test cement was accurately weighed in a platinum crucible and mixed with $9.000 \mathrm{~g}$ of lithium tetraborate as a flux. The resultant mixture was fused in a M4 gas fusion unit for a period of 17 minutes to form a glass bead. The formed glass beads were kept in a desiccator to cool before transferred into the XRF unit for analysis. Each test cement was analysed in triplicates, and the average values are tabulated as shown in Table 1.

2.2.2. Determination of Loss on Ignition (LOI). Triplicate samples of each test cement were subjected to the loss on ignition test. LOI was determined gravimetrically as described in KS EAS 18:1-2017 [23]. 1.000 g of each test cement was accurately weighed and transferred in a silica crucible that had already been weighed and tared. The crucible with the sample was then placed in a furnace set at $975^{\circ} \mathrm{C}$ for a period of 1 hour. The crucible with the sample was cooled in a desiccator. LOI was expressed as a percentage of the difference of the mass before and after ignition.

2.2.3. Microbial Culturing of Starkeya novella. Culturing of Starkeya novella was conducted at microbiology laboratories of the University of Embu, Kenya. The medium for the bacteria growth was formulated as described in the DSMZ manual. Definite amount of each of the reagents was accurately weighed and dissolved in $1000 \mathrm{~mL}$ of distilled water as shown in Table 2. The $\mathrm{pH}$ of the resultant solution was 
TABLE 2: Composition for microbial culture DSM 506.

\begin{tabular}{lc}
\hline Chemical ingredient & Quantity in grams \\
\hline $\mathrm{CaCl}_{2}$ & 0.10 \\
$\mathrm{~K}_{2} \mathrm{HPO}_{4}$ & 4.00 \\
$\mathrm{MgSO}_{4} \cdot 7 \mathrm{H}_{2} \mathrm{O}$ & 0.10 \\
$\mathrm{MnSO}_{4} \cdot \mathrm{H}_{2} \mathrm{O}$ & 0.02 \\
$\left(\mathrm{NH}_{4}\right)_{2} \mathrm{SO}_{4}$ & 0.10 \\
$\mathrm{Agar}$ & 12.00 \\
$\mathrm{FeCl}_{2} \cdot 6 \mathrm{H}_{2} \mathrm{O}$ & 0.02 \\
$\mathrm{Na}_{2} \mathrm{SO}_{3} \cdot 5 \mathrm{H}_{2} \mathrm{O}$ & 10.00 \\
\hline
\end{tabular}

adjusted to 6.6 using a mixture of $\mathrm{Na}_{2} \mathrm{CO}_{3}$ and $\mathrm{NaHCO}_{3}$. This was done to meet the desired optimal growth of the bacterium. The achieved solution was sterilized by autoclaving at a temperature of $125^{\circ} \mathrm{C}$. The sterilized solution was then cooled to a room temperature, and pure spores of Starkeya novella were carefully added. $10.0 \mathrm{~g}$ of $\mathrm{Na}_{2} \mathrm{SO}_{3} \cdot 5 \mathrm{H}_{2} \mathrm{O}$ and $12.0 \mathrm{~g}$ of agar were added to serve as the source of nutrients to the bacteria. Incubation was carried out in a shaker kept at a temperature of $30^{\circ} \mathrm{C}$ for a period of 5 days. Bacterial concentration was maintained at $1.0 \times 10^{7} \mathrm{cell} / \mathrm{mL}$. The obtained bacterial solution was preserved in a sterilized container for use in mixing and curing of mortar samples.

2.2.4. Preparation of Mortar Prisms. Test cements were prepared and casted in moulds of size $40 \mathrm{~mm} \times 40 \mathrm{~mm} \times$ $160 \mathrm{~mm}$ as defined in KS EAS 148:1-2000 [25]. The test mortar prisms were prepared from both OPC and PPC. In each test cement, three sets of tests were conducted. The first set was the control sample which was cast and cured in distilled water. This particular set was labelled as $\mathrm{OPC} \mathrm{H}_{2} \mathrm{O}$ $\left(\mathrm{H}_{2} \mathrm{O}\right)$ and $\mathrm{PPC} \mathrm{H}_{2} \mathrm{O}\left(\mathrm{H}_{2} \mathrm{O}\right)$. The second set involved preparation of test cement with bacterial solution as mix water and cured in distilled water. This particular set up was labelled as OPC SK $\left(\mathrm{H}_{2} \mathrm{O}\right)$ and PPC SK $\left(\mathrm{H}_{2} \mathrm{O}\right)$. The third set up involved casting of test cements with bacteria solution as mix water and curing of the mortar prisms in the bacterial solution. This particular set up was labelled as OPC SK (SK) and PPC SK (SK). In all scenarios, a standard water-tocement ratio $(\mathrm{w} / \mathrm{c})$ of 0.5 was used. The prepared mortar prims were kept in a humidity cabinet after casting for a period of 24 hours with the temperature and relative humidity maintained at $20^{\circ} \mathrm{C} \pm 2^{\circ} \mathrm{C}$ and above $95 \%$, respectively. Demoulding was done after 24 hours, and the mortar prisms cured in respective curing media maintained at room temperature.

2.2.5. Determination of Compressive Strength. The compressive strength for both OPC and PPC mortars prepared and cured in different regimes as described in 2.2.2 was determined in accordance with KS EAS 148:1-2000 [25]. The mortar prism to be tested for strength was placed at the center of the platens of the compressive machine within $\pm 0.5 \mathrm{~mm}$ and longitudinally such that the end face of the test prism overhang the platens or the auxiliary plates by about $10 \mathrm{~mm}$. Increase of the load was done smoothly at the rate of
$2400 \pm 200 \mathrm{~N} / \mathrm{s}$ over the entire load application until fracture. The strength development was determined after the $7^{\text {th }}, 28^{\text {th }}$, $56^{\text {th }}$, and $90^{\text {th }}$ day of curing using the compressive strength model YAW-300. The results obtained were expressed in Mpa.

2.2.6. Scanning Electron Microscopy (SEM). The test samples, OPC $\mathrm{H}_{2} \mathrm{O}\left(\mathrm{H}_{2} \mathrm{O}\right)$, PPC $\mathrm{H}_{2} \mathrm{O}\left(\mathrm{H}_{2} \mathrm{O}\right)$, OPC SK $\left(\mathrm{H}_{2} \mathrm{O}\right)$, PPC SK $\left(\mathrm{H}_{2} \mathrm{O}\right)$, OPC SK (SK), and PPC SK (SK), were subjected to SEM analysis after the $28^{\text {th }}$ day of curing. SEM analysis was conducted at the University of Pretoria, South Africa, using the SEM model Zeiss Ultra Plug FEG-SEM. A guide for microstructural analysis of cementitious materials provided by Scrivener et al., 2017 [26] was adopted in carrying out the SEM test.

\section{Results and Discussion}

3.1. Compressive Strength Development. Figures 1 and 2 show compressive strength development of control and microbial mortars of PPC and OPC prepared and cured in different regimes as described in section 2.2.2, respectively. The compressive strength of control mortars, PPC $\mathrm{H}_{2} \mathrm{O}$ $\left(\mathrm{H}_{2} \mathrm{O}\right)$ and OPC $\mathrm{H}_{2} \mathrm{O}\left(\mathrm{H}_{2} \mathrm{O}\right)$, met the minimum strength requirement of $32.5 \mathrm{MPa}$ and $42.5 \mathrm{MPa}$ after 28 days of curing. This is as described in KS EAS 18:1- 2017 [23].

As observed, OPC $\mathrm{H}_{2} \mathrm{O}\left(\mathrm{H}_{2} \mathrm{O}\right)$ exhibited high compressive strength than $\mathrm{PPC} \mathrm{H}_{2} \mathrm{O}\left(\mathrm{H}_{2} \mathrm{O}\right)$ at all curing ages. OPC being a pure cement has high levels of $\mathrm{C}_{3} \mathrm{~S}$ and $\mathrm{C}_{3} \mathrm{~A}$ phases that aid in hydration and hence promote strength development. PPC due to pozzolana addition exhibits low heat of hydration resulting in decreased early strength. The strength of PPC develops with time due to pozzolanic activity. Similar observations were made by Munyao 2015 [27] and Muthengia, 2009 [28].

The compressive strength of PPC microbial mortars, PPC SK $\left(\mathrm{H}_{2} \mathrm{O}\right)$ and PPC SK (SK), exhibited similar strength as the control mortar $\mathrm{PPC} \mathrm{H}_{2} \mathrm{O}\left(\mathrm{H}_{2} \mathrm{O}\right)$ at 7 days of curing. This could have been attributed to slow growth of the microbes and hence too early to detect the deleterious effect. A similar trend was noted in OPC microbial mortars, OPC SK $\left(\mathrm{H}_{2} \mathrm{O}\right)$ and OPC SK (SK), at 7 days. However, the strength decrease was observed in microbial mortars for both test cements after $28^{\text {th }}$ days of curing. Figures 3 and 4 show compressive strength decrease of microbial mortars for PPC and OPC.

As shown in Figures 3 and 4, the compressive strength of PPC and OPC microbial mortars decreased with increase in the curing period. While there was a reported decrease in strength for the mortars prepared with bacterial solution and cured in water, denoted as PPC SK $\left(\mathrm{H}_{2} \mathrm{O}\right)$ and OPC SK $\left(\mathrm{H}_{2} \mathrm{O}\right)$, the extreme effect was observed on test prisms prepared and cured in bacterial solution, denoted as PPC SK (SK) and OPC SK (SK). This could perhaps be attributed to the deleterious effect of the Starkeya novella bacteria. Adverse effect was observed at the $90^{\text {th }}$ day of curing with OPC SK (SK) reporting a decrease of $34.25 \%$ against $17.94 \%$ in PPC SK (SK). The decline in compressive strength was 


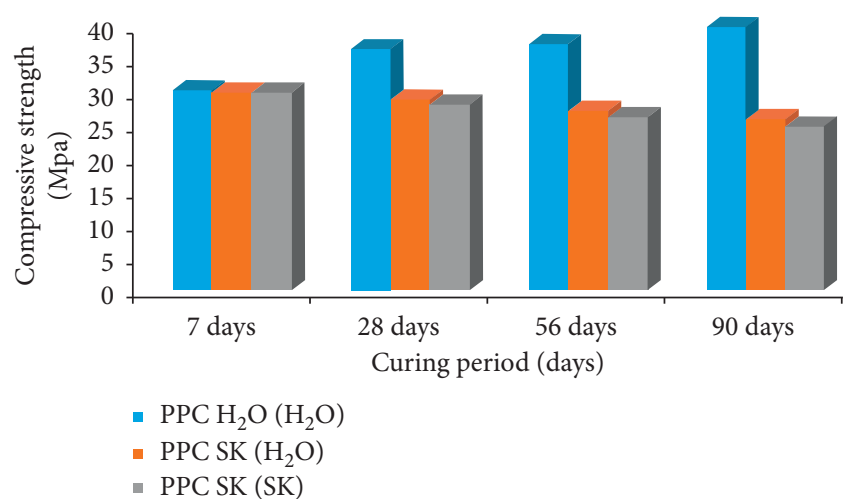

FIgURE 1: Compressive strength performance of control and microbial PPC mortars at different curing ages.

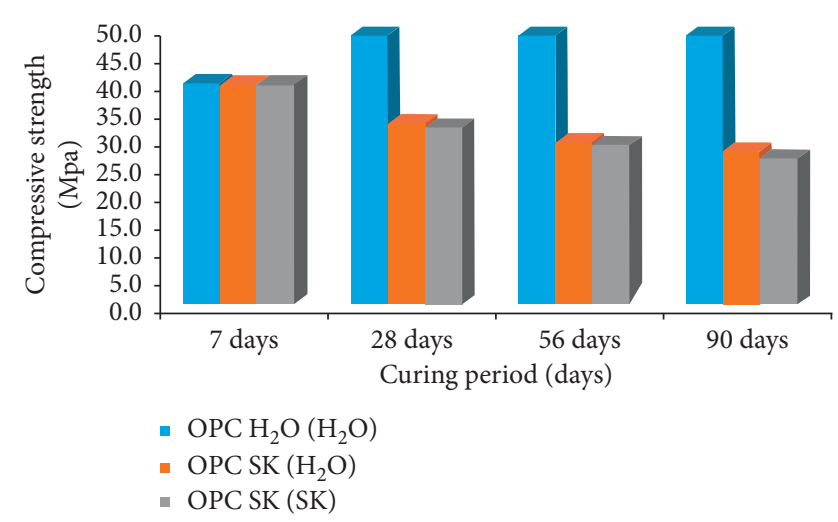

Figure 2: Compressive strength performance of control and microbial OPC mortars at different curing ages.

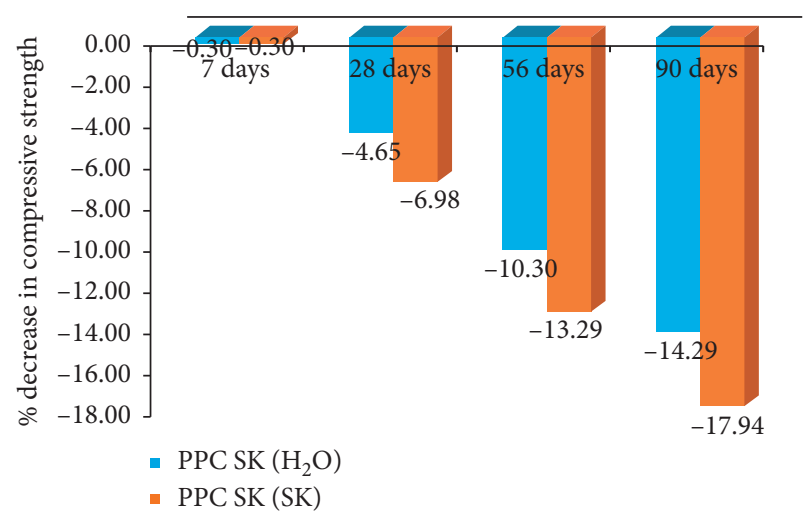

Figure 3: Percentage decrease in compressive strength of PPC microbial mortars.

attributed to biogenic sulphuric acid formed as a result of Starkeya novella activity. According to Starkey, 1935 [21], Thiobacillus novellus currently referred to as Starkeya novella species has the ability to oxidize thiosulfates present in soil into biogenic sulphuric acid. Furthermore, George et al., [29] observed that exposure of bacterial concrete to air and $\mathrm{H}_{2} \mathrm{~S}$ results in oxidation of sulphur compounds to form $\mathrm{H}_{2} \mathrm{SO}_{4}$ which attacks and disintegrates the concrete.

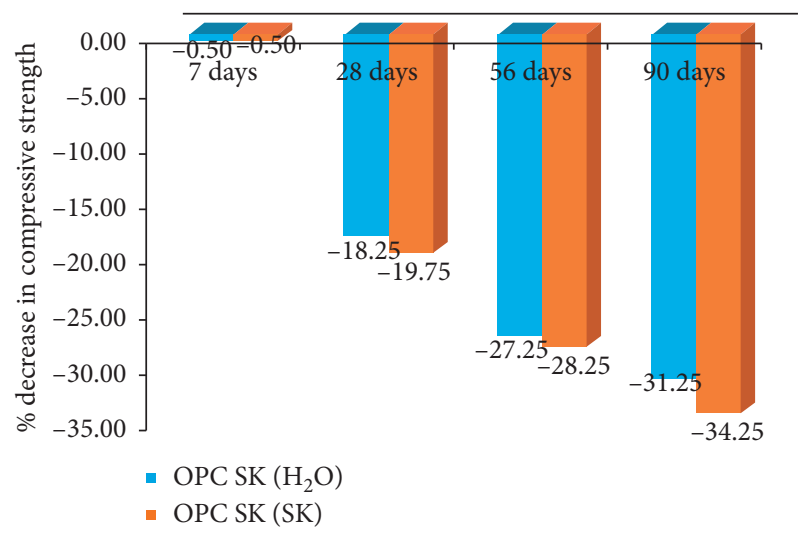

FIgURE 4: Percentage decrease in compressive strength of OPC microbial mortars.

OPC is more prone to acid attack than PPC due to high amount of calcium hydroxide $(\mathrm{CH})$. The formed $\mathrm{H}_{2} \mathrm{SO}_{4}$ may react with calcium hydroxide $(\mathrm{CH})$ in the pore solution to form additional gypsum $\left(\mathrm{CS}_{\bar{S}} \mathrm{H}_{2}\right)$. The formed $\mathrm{C} \overline{\mathrm{S}} \mathrm{H}_{2}$ reacts with the $\mathrm{C}_{3} \mathrm{~A}$ phase in cement to form ettringite (AFt) which is an expansive product. This is as shown in equations (1) and (2). Presence of ettringite (AFt) in concrete results in cracking. The formed cracks form suitable pathways for ingress of other harmful materials to the concrete matrix:

$$
\begin{aligned}
& \mathrm{Ca}(\mathrm{OH})_{2}+\mathrm{H}_{2} \mathrm{SO}_{4} \longrightarrow \mathrm{CaSO}_{4} \cdot 2 \mathrm{H}_{2} \mathrm{O}, \\
& \mathrm{C}_{3} \mathrm{~A}+3 \mathrm{C} \overline{\mathrm{S}} \mathrm{H}_{2}+26 \mathrm{H} \longrightarrow \mathrm{C}_{6} \mathrm{AS}_{3} \mathrm{H}_{32} .
\end{aligned}
$$

3.2. Scanning Electron Microscopy (SEM) Results. The results of SEM analysis are presented in Figures 5-10. Figures 5-7 show OPC $\mathrm{H}_{2} \mathrm{O}\left(\mathrm{H}_{2} \mathrm{O}\right)$, OPC $\mathrm{H}_{2} \mathrm{O}$ (SK), and OPC SK (SK), whereas Figures 8-10 show the results of $\mathrm{PPC} \mathrm{H}_{2} \mathrm{O}\left(\mathrm{H}_{2} \mathrm{O}\right)$, PPC $\mathrm{H}_{2} \mathrm{O}$ (SK), and PPC SK (SK). All the test samples were subjected to SEM analysis after 28 days of curing. In all the scenarios, there was a significant comparison of the SEM micrographs with other researchers' works already published [17, 30, 31].

The SEM image for the OPC control sample, OPC $\mathrm{H}_{2} \mathrm{O}$ $\left(\mathrm{H}_{2} \mathrm{O}\right)$, as shown in Figure 5 was characterized by homogenous distribution of calcium hydroxide $(\mathrm{CH})$ plates and calcium silicate hydrate (C-S-H) phase as the key hydration products. The presence of the needle-shaped crystals referred to as ettringite (AFt) could have perhaps been as a result of sulphate content from gypsum that is added to the ordinary Portland cement (OPC) to control the setting time and improve on the cement workability. There was no observable crack in the morphology of the control sample.

High presence of ettringite (AFt) and eroded $\mathrm{CH}$ plates was observed in OPC SK $\left(\mathrm{H}_{2} \mathrm{O}\right)$ as shown in Figure 6. Presence of high sulphate content provides a suitable environment for the development of ettringite. This was attributed to the metabolic activity of the Starkeya novella. According to Diercks et al., 1991 [32], and Sand and Bock, 1984 [33], presence of sulphur oxidizing bacteria (SOB) in 


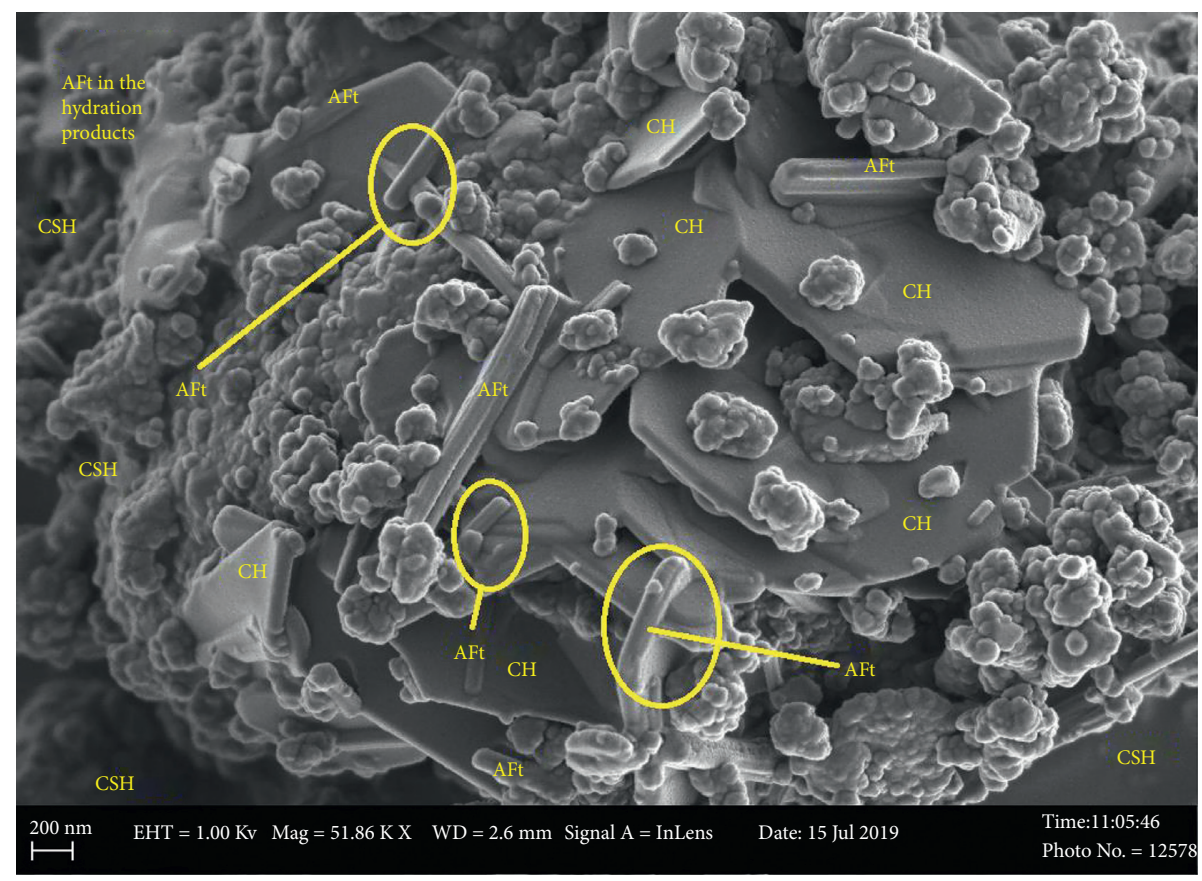

Figure 5: OPC $\mathrm{H}_{2} \mathrm{O}\left(\mathrm{H}_{2} \mathrm{O}\right)$.

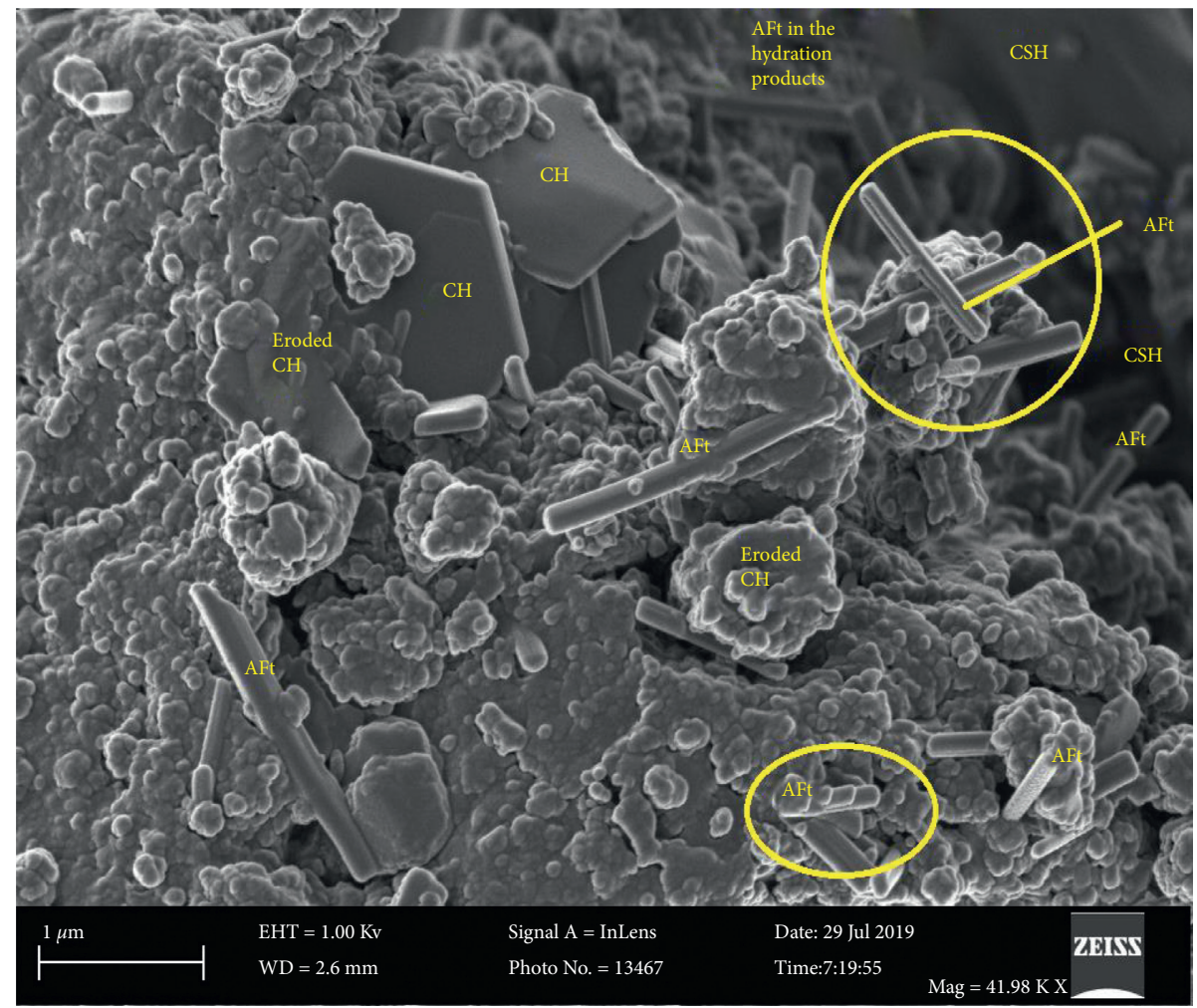

Figure 6: OPC SK $\left(\mathrm{H}_{2} \mathrm{O}\right)$.

the sewer set up results in production of biogenic sulphuric acid. The formed biogenic sulphuric acid attacks $\mathrm{CH}$ and $\mathrm{C}-\mathrm{S}-\mathrm{H}$ as the key hydration products of OPC leading to formation of secondary expansive materials such as gypsum and ettringite [34, 35]. Similar observations were made by Munyao et al., 2020 [17], and Buvignier et al., 2019 [10].
The SEM image for OPC SK (SK) as presented in Figure 7 was dominated by excessive formation of ettringite and microcracks with elaborate erosion of $\mathrm{CH}$ plates. The formed microcracks were attributed to excessive internal pressure resulting from formation of secondary ettringite and gypsum. This exposes concrete 


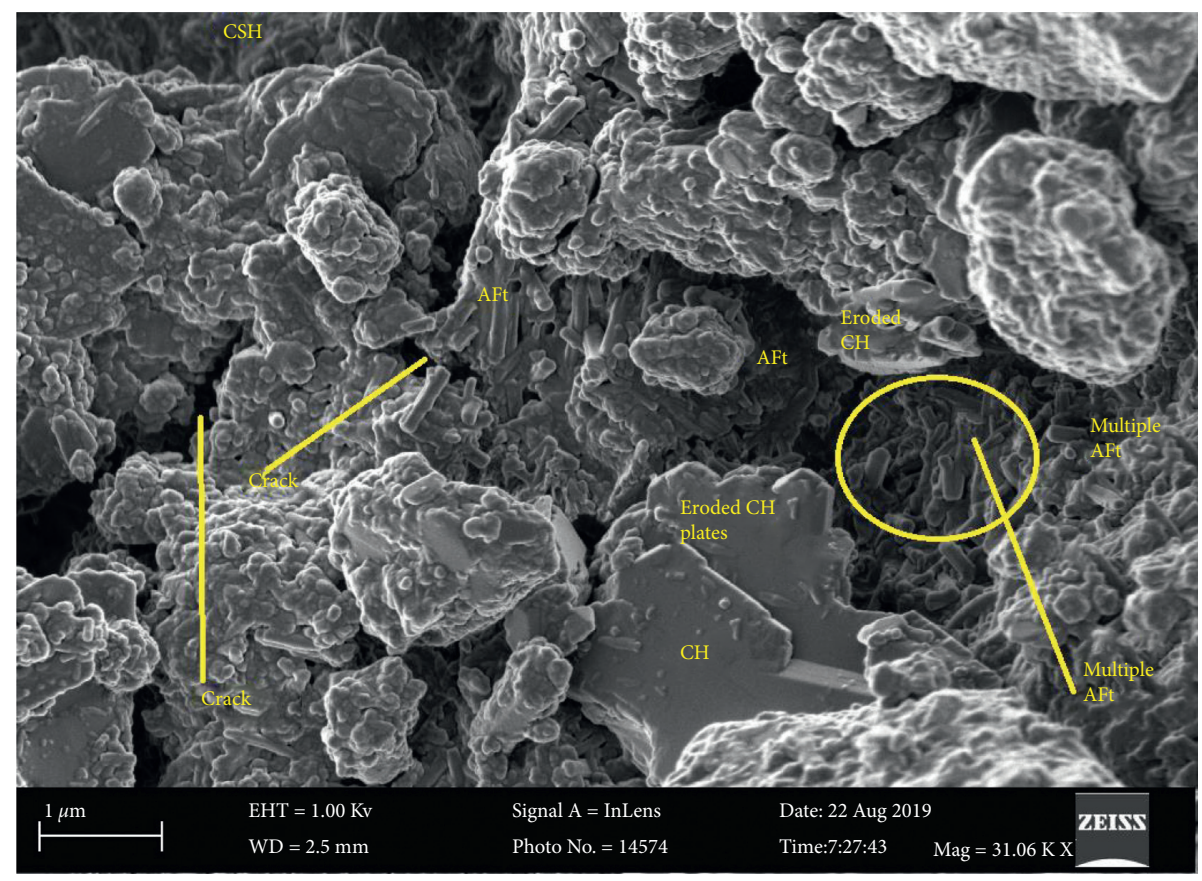

Figure 7: OPC SK (SK).

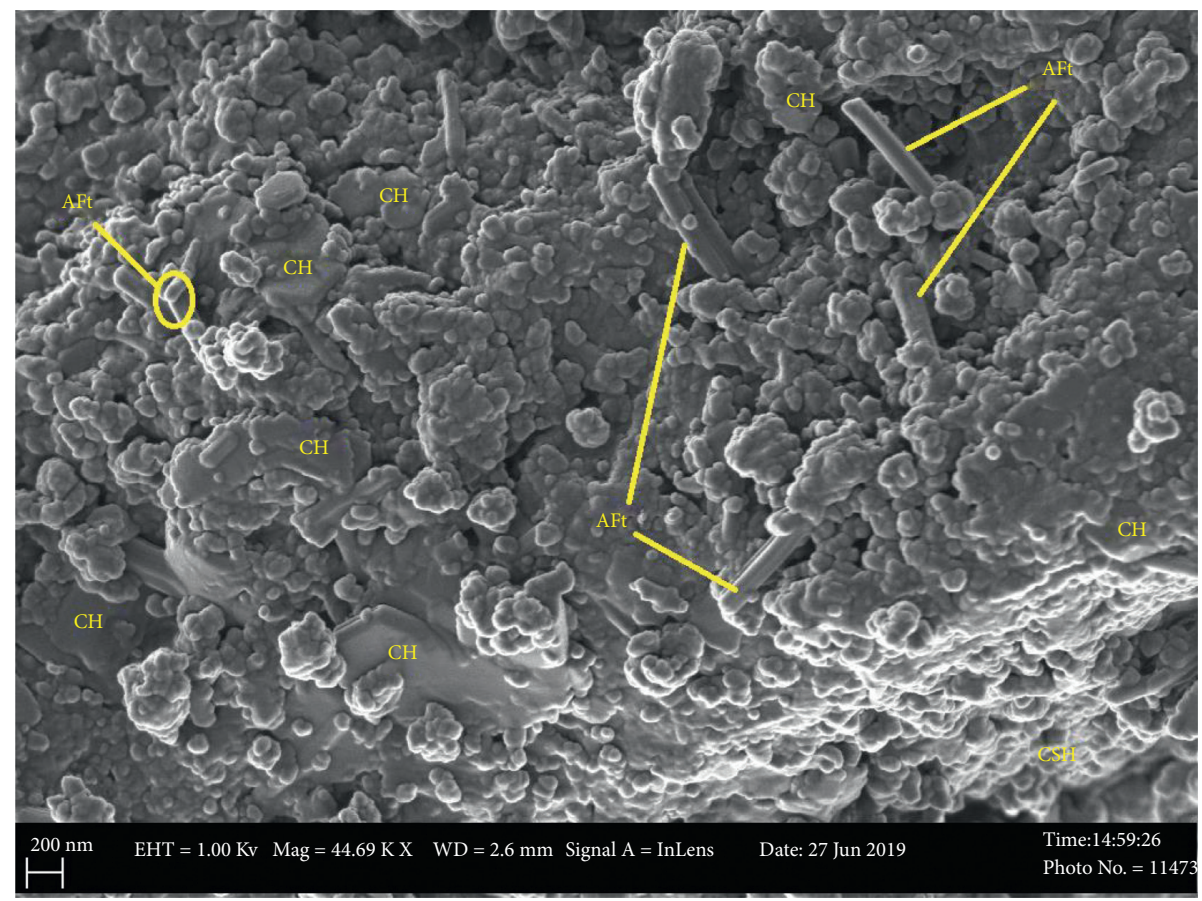

Figure 8: PPC $\mathrm{H}_{2} \mathrm{O}\left(\mathrm{H}_{2} \mathrm{O}\right)$.

structure to possible degradation. Joshi et al., 2019 [3], reported concrete cracking and spalling as a result of gypsum and ettringite build up in the pore system of the cementitious matrix. Similar observations were made by Maes and De Belie, 2014 [36], Tian and Cohen [37], and Roziere et al., 2009 [38].

The SEM results for the control PPC sample, $\mathrm{PPC} \mathrm{H}_{2} \mathrm{O}$ $\left(\mathrm{H}_{2} \mathrm{O}\right)$, exhibited reduced $\mathrm{CH}$ plates as compared to control
OPC, OPC $\mathrm{H}_{2} \mathrm{O}\left(\mathrm{H}_{2} \mathrm{O}\right)$. This was attributed to higher clinker portion in OPC.

Ettringite crystals were observed on the surface of the PPC control mortar as shown in Figure 8. This was attributed to the gypsum added to control the setting time and improve on the workability of the cement. The ettringite was not as pronounced as compared to OPC control mortar shown in Figure 5. This was perhaps due to reduced $\mathrm{C}_{3} \mathrm{~A}$ 


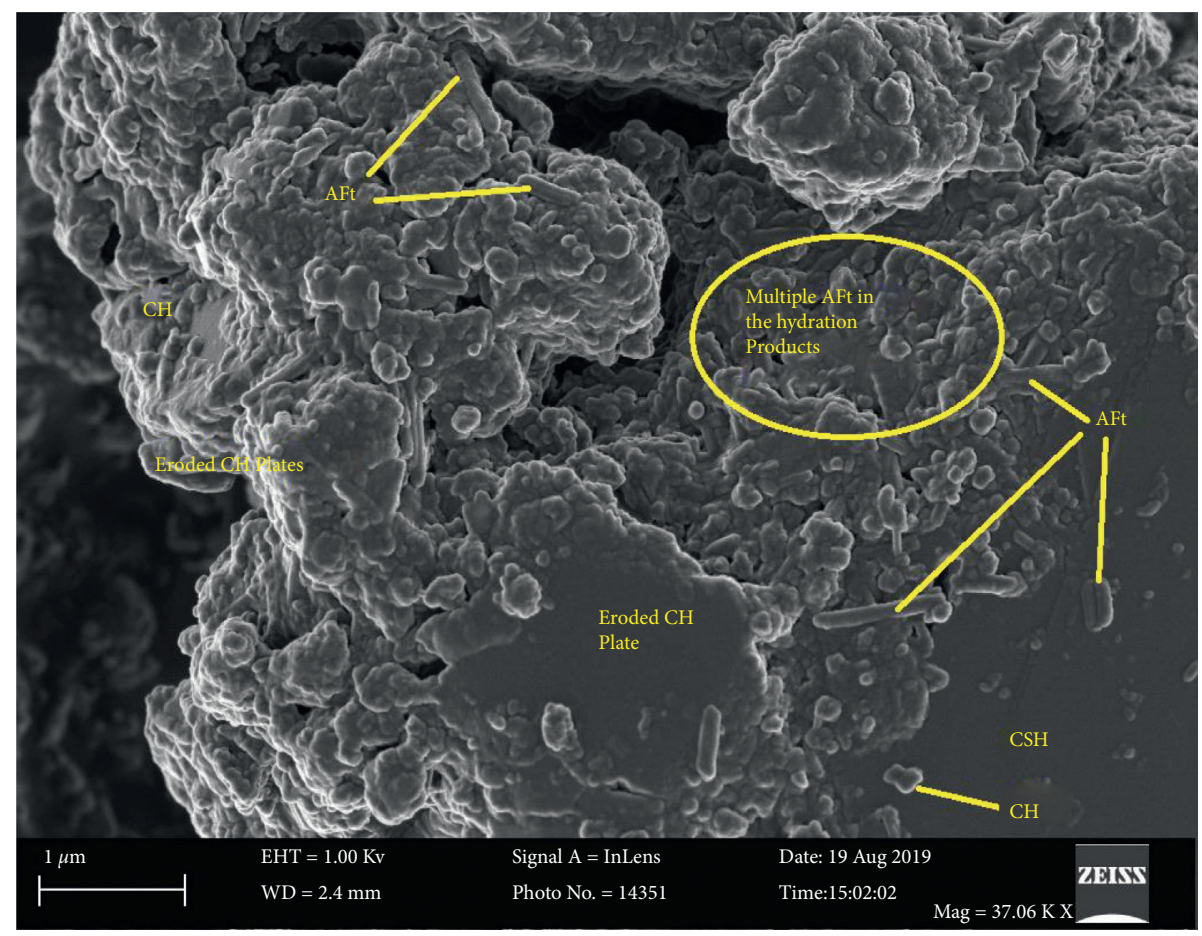

Figure 9: PPC SK $\left(\mathrm{H}_{2} \mathrm{O}\right)$.

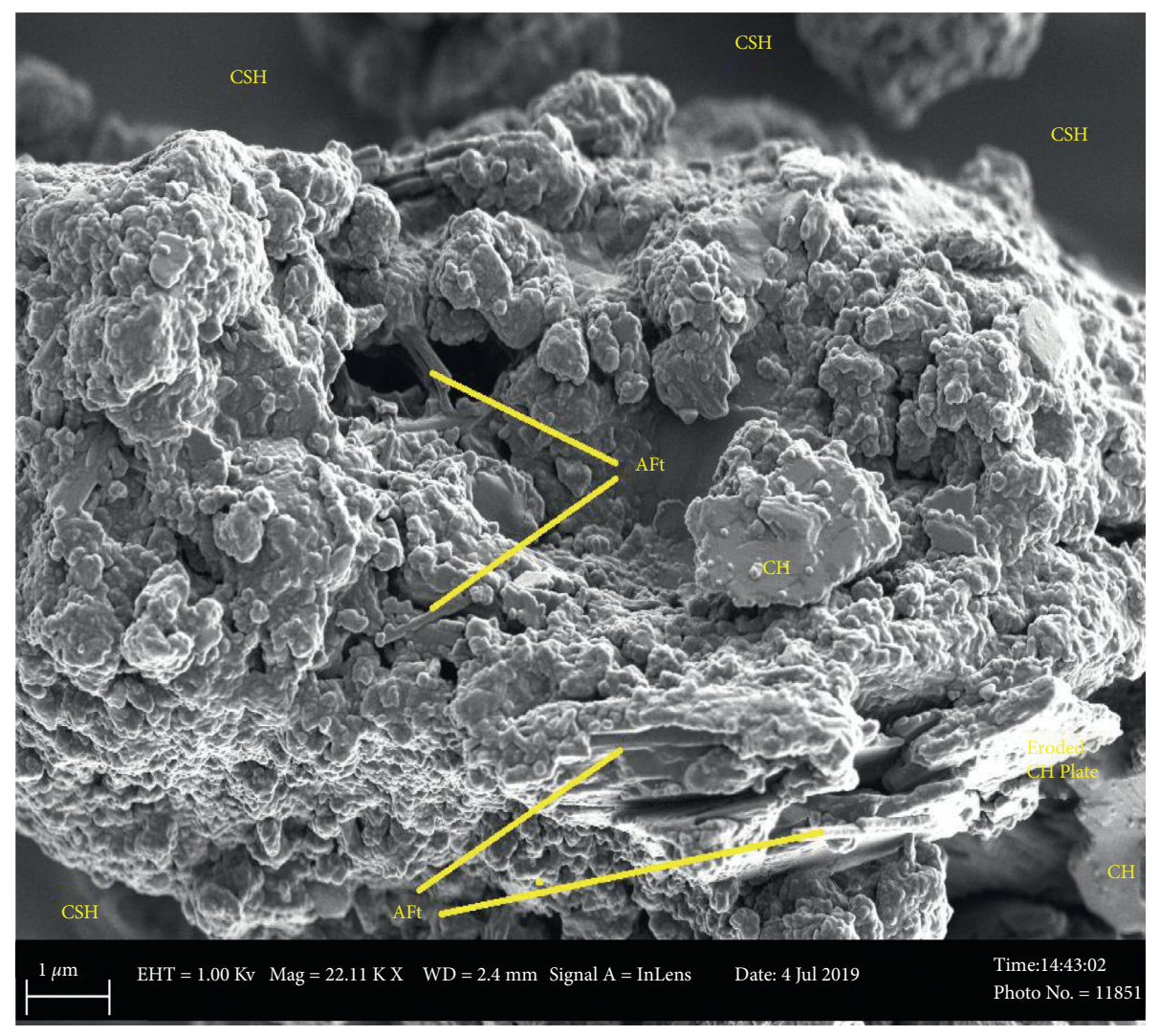

Figure 10: PPC SK (SK). 
content in PPC which provides a conducive environment for the development of ettringite.

There was significant decrease in $\mathrm{CH}$ plates for the control PPC as compared to control OPC. This was attributed to pozzolanic activity. Silica and aluminate content from pozzolana reacts with $\mathrm{CH}$ to form additional $\mathrm{CSH}$ and $\mathrm{CAH}$ as shown in equations (3) and (4) $[27,39]$. The formed cementitious products make the resultant mortar denser and less permeable to attack by aggressive media. Similar observations were made by Muthengia, 2009 [28]. While there was appreciable increase in ettringite formation on bacterial treated mortars as shown in Figures 9 and 10, it was not as aggressive as observed in OPC bacterial treated mortars. This again was explained by the pozzolana reaction that hinders the attack of the resultant mortar from aggressive media [40]:

$$
\begin{gathered}
2 \mathrm{SiO}_{2}+3 \mathrm{Ca}(\mathrm{OH})_{2}+5 \mathrm{H}_{2} \mathrm{O} \longrightarrow 3 \mathrm{CaO} \cdot \mathrm{SiO}_{2} \cdot 8 \mathrm{H}_{2} \mathrm{O} \\
\mathrm{Al}_{2} \mathrm{O}_{3}+4 \mathrm{Ca}(\mathrm{OH})_{2}+9 \mathrm{H}_{2} \mathrm{O} \longrightarrow 4 \mathrm{CaO} \cdot \mathrm{Al}_{2} \mathrm{O}_{3} \cdot 13 \mathrm{H}_{2} \mathrm{O}
\end{gathered}
$$

\section{Conclusion}

Based on the results of this work, Starkeya novella was found to reduce the compressive strength of both OPC and PPC mortars significantly. This has a negative impact on the durability of structures exposed in such conditions. It was noted that OPC and PPC mortars prepared using distilled water and cured in bacteria solution denoted as $\mathrm{OPC} \mathrm{H}_{2} \mathrm{O}$ (SK) and PPC $\mathrm{H}_{2} \mathrm{O}(\mathrm{SK})$ had a compressive strength decrease of $31.25 \%$ and $14.29 \%$, respectively, whereas for OPC SK (SK) and PPC SK (SK), the strength decrease was 34.25\% and $17.94 \%$, respectively. It was further noted that Starkeya novella actively attacks OPC mortars more than PPC. This was evident from both the compressive strength and SEM results.

\section{Data Availability}

The data used to support the findings of work are available upon request through the corresponding author.

\section{Conflicts of Interest}

The authors declare no conflicts of interest.

\section{Acknowledgments}

The authors recognize the great support offered by Savannah Cement Limited, Kenya, where the mortar preparation and testing were conducted, the microbiology laboratory of the University of Embu, where the growth of the media culture was done, and Kenyatta University for providing library materials. Special thanks are due to Anton Weavind, the director of Starex (Pty) Ltd, South Africa, for facilitating scanning electron microscopy analysis at the laboratory of microscopic analysis, University of Pretoria, South Africa. This work was supported by the African Development Bank in collaboration with the Ministry of Education, Science, and Technology, Kenya.

\section{References}

[1] O. M. Munyao, J. K. Thiong'o, J. M. Wachira, D. K. Mutitu, M. Roman, and G. Murithi, "Use of Bacillus Species bacteria in protecting the concrete structures from sulphate attack- a review," Journal of Chemical Reviews, vol. 1, no. 4, pp. 287299, 2019.

[2] N. Parastegari, D. Mostofinejad, and D. Poursina, "Use of bacteria to improve electrical resistivity and chloride penetration of air-entrained concrete," Construction and Building Materials, vol. 210, pp. 585-595, 2019.

[3] S. Joshi, S. Goyal, A. Mukherjee, and M. S. Reddy, "Protection of concrete structures under sulfate environments by using calcifying bacteria," Construction and Building Materials, vol. 209, pp. 156-166, 2019.

[4] H. A. Khan, A. Castel, M. S. H. Khan, and A. H. Mahmood, "Durability of calcium aluminate and sulphate resistance Portland cement based mortars in aggressive sewer environment and sulphuric acid," Cement and Concrete Research, vol. 124, Article ID 105852, 2019.

[5] G. Escadeillas, A. Bertron, P. J. Blanc, and A. Dubosc, "Accelerated testing of biological stain growth on external concrete walls. Part 1: Development of the Growth Tests," Materials and Structures, vol. 40, pp. 1061-1071, 2007.

[6] C. Parker, "The corrosion of concrete," Australian Journal of Experimental Biology and Medical Science, vol. 23, no. 2, pp. 81-90, 1945.

[7] Z. Makhloufi, E. H. Kadri, M. Bouhicha, and A. Benaissa, "Resistance of limestone mortars with quaternary binders to sulfuric acid solution," Construction and Building Materials, vol. 26, pp. 497-504, 2012.

[8] H. Yuan, P. Dangla, P. Chatellier, and T. Chaussadent, "Degradation modelling of concrete submitted to sulfuric acid attack," Cement and Concrete Research, vol. 53, pp. 267-277, 2013.

[9] T. Wells and R. E. Melchers, "Modelling concrete deterioration in sewers using theory and field observations," Cement and Concrete Research, vol. 77, pp. 82-96, 2015.

[10] A. Buvignier, C. Patapy, M. P. Lavigne, and E. Paul, "Resistance to biodeterioration of aluminium-rich binders in sewer network environment: study of the possible bacteriostatic effect and role of phase reactivity," Cement and Concrete Research, vol. 123, Article ID 105785, 2019.

[11] T. Haile, G. Nakhla, and E. Allouche, "Evaluation of the resistance of mortars coated with silver bearing zeolite to bacterial-induced corrosion," Corrosion Science, vol. 50, no. 3 , pp. 713-720, 2008.

[12] H. S. Jensen, Hydrogen Sulfide Induced Concrete Corrosion of Sewer Networks, Aalborg University, Aalborg, Denmark, 2009.

[13] M. O'. Conwell, C. McNally, and M. G. Richardson, "Biochemical attack on concrete in waste water application: a state of the art review," Cement and Concrete Composite, vol. 32, pp. 479-485, 2010.

[14] A. Bertron, "Understanding interactions between cementitious materials and microorganisms: a key to sustainable and safe concrete structures in various contexts," Materials and Structures, vol. 47, no. 11, pp. 1787-1806, 2014.

[15] C. Grengg, F. Mittermayr, G. Koraimann et al., "The decisive role of acidophilic bacteria in concrete sewer networks: a new 
model for fast progressing microbial concrete corrosion," Cement and Concrete Research, vol. 101, pp. 93-101, 2017.

[16] M. G. Alexander and C. Fourie, "Performance of sewer pipe concrete mixtures with portland and calcium aluminate cements subject to mineral and biogenic acid attack," Materials and Structures, vol. 44, no. 1, pp. 313-330, 2011.

[17] O. M. Munyao, J. K. Thiong'o, J. W. Muthengia et al., "Study on the effect of Thiobacillus intermedius on the physicomechanical properties of mortars of ordinary portland cement," Heliyon, vol. 6, Article ID e03232, 2020.

[18] T. Mori, T. Nonaka, K. Tazaki, M. Koga, Y. Hikosaka, and S. Noda, "Interactions of nutrients, moisture and $\mathrm{pH}$ on microbial corrosion of concrete sewer pipes," Water Research, vol. 26, no. 1, pp. 29-37, 1992.

[19] R. Pomeroy and J. Parkhurst, "The forecasting of sulfide buildup rates in sewers," Progress in Water Technology, vol. 9, no. 3, pp. 621-628, 1977.

[20] R. L. Starkey, "Cultivation of organisms concerned in the oxidation of thiosulfate," Journal of Bacteriology, vol. 28, pp. 195-213, 1934.

[21] R. L. Starkey, "Isolation of some bacteria which oxidize thiosulfate," Soil Science, vol. 39, no. 3, pp. 197-220, 1935.

[22] W. Vishniac and M. Santer, "The thiobacilli, 12," Bacteriological Reviews, vol. 21, no. 3, pp. 195-213, 1957.

[23] KS EAS 18 -1, Kenya Standard Test Methods for Oxide Specification of Hydraulic Cement, Kenya Bureau of Standards, Nairobi, Kenya, 2017.

[24] EN 196 -1, Cement Part 1: Determination of Strength, European Union of Standards, Beckum, Germany, 2016.

[25] KS EAS 148:1, Kenya Standard Test Method for Determination of Cement Strength, Kenya Bureau of Standards, Nairobi, Kenya, 2000.

[26] K. Scrivener, R. Snellings, and B. Lothenbach, A practical guide to microstructural analysis of cementitious materials, CRC Press, Boca Raton, FL, USA, 1st edition, 2017.

[27] O. M. Munyao, "Effects of surface and subsurface mixing water of Nairobi, Machakos and Kajiado Counties on cement mortar performance," Msc Thesis, Department of Chemistry, Kenyatta University, Nairobi, Kenya, 2015.

[28] J. W. Muthengia, "Effects of selected media on novel Portland Pozzolana cement," PhD Thesis, Department of Chemistry, Kenyatta University, Nairobi, Kenya, 2009.

[29] R. P. George, S. Ramya, D. Ramachandran, and U. K. Mudali, "Studies on biodegradation of normal concrete surface by fungus Fusarium species," Cement and Concrete Research, vol. 47, pp. 8-13, 2013.

[30] K. Vijay, M. Murmu, and S. V. Deo, "Bacteria based self healing concrete-a review," Construction and Building Materials, vol. 152, pp. 1008-1014, 2017.

[31] P. Feng, E. J. Garboczi, C. Miao, and J. W. Bullard, "Microstructural origins of cement paste degradation by external sulfate attack," Construction and Building Materials, vol. 96, pp. 391-403, 2015.

[32] M. Diercks, W. Sand, and E. Bock, "Microbial corrosion of concrete," Experientia, vol. 47, no. 6, pp. 514-516, 1991.

[33] W. Sand and E. Bock, "Concrete corrosion in the hamburg sewer system," Environmental Technology Letters, vol. 5, no. 12 , pp. 517-528, 1984.

[34] D. J. Roberts, D. Nica, G. Zuo, and J. L. Davis, "Quantifying microbially induced deterioration of concrete: initial studies," International Biodeterioration \& Biodegradation, vol. 49, no. 4, pp. 227-234, 2002.

[35] M. W. Kiliswa, Composition and Microstructure of Concrete Mixtures Subjected to Biogenic Sulphuric Acid Corrosion and
Their Role in Corrosion Prediction of Concrete Outfall Sewers, Ph.D, Thesis, University of Cape Town, Cape Town, South Africa, 2016.

[36] M. Maes and N. De Belie, "Resistance of concrete and mortar against combined attack of chloride and sodium sulphate," Cement and Concrete Composites, vol. 53, pp. 59-72, 2014.

[37] B. Tian and M. D. Cohen, "Does gypsum formation during sulfate attack on concrete lead to expansion ?" Cement and Concrete Research, vol. 30, no. 1, pp. 117-123, 2000.

[38] E. Rozière, A. Loukili, R. El Hachem, and F. Grondin, "Durability of concrete exposed to leaching and external sulphate attacks," Cement and Concrete Research, vol. 39, no. 12, pp. 1188-1198, 2009.

[39] H. F. W. Taylor, Cement Chemistry, pp. 8-128, Taylor and Thomas Telford Services LTD, London, UK, 1999.

[40] K. O. Ampadu and K. Torii, "Chloride ingress and steel corrosion in cement mortars incorporating low-quality fly ashes," Cement and Concrete Research, vol. 32, no. 6, pp. 893-901, 2002. 